\title{
Photocatalytic Degradation of Indigo Carmine Dye Using Calcium Oxide
}

\author{
Kirana Devarahosahalli Veeranna, Madhu Theeta Lakshamaiah, \\ and Ramesh Thimmasandra Narayan
}

Department of Studies and Research in Chemistry and Professor C. N. R. Rao Centre for Advanced Materials, Tumkur University, Tumkur 572 103, India

Correspondence should be addressed to Ramesh Thimmasandra Narayan; adityaramesh77@yahoo.com

Received 8 August 2014; Accepted 17 November 2014; Published 3 December 2014

Academic Editor: M. El-Khouly

Copyright (C) 2014 Kirana Devarahosahalli Veeranna et al. This is an open access article distributed under the Creative Commons Attribution License, which permits unrestricted use, distribution, and reproduction in any medium, provided the original work is properly cited.

Calcium oxide was used as photocatalyst for the degradation of indigo carmine dye solution in the visible, long UV, and short UV radiation. We have investigated the effectiveness of degradation of indigo carmine dye solution at pH 9 and 12 using calcium oxide with the particle size of $30-36 \mathrm{~nm}$ by varying the concentration, dose of adsorbent, and duration. It has been found that the degradation of indigo carmine dye is effective at $\mathrm{pH}=9$, when $0.12 \mathrm{~g}$ of calcium oxide was used. The nature of interaction between calcium oxide and indigo carmine dye was discussed.

\section{Introduction}

The water bodies are continuously polluted due to the unscientific methods adopted by the chemical, textile, paper, and pulp industries, and so forth, during the discharge of toxic and hazardous chemicals [1-5]. Complexity of the dye molecules does not favour the natural process of degradation and also during certain instances incomplete degradation or transformation may generate carcinogenic byproducts [69]. Therefore, physical, chemical, and biological methods have been developed for the treatment of dye effluents from industries [10]. Precipitation, coagulation, floatation, and oxidizing agents have been used for the treatment of different types of dyes. Major disadvantages of chemical methods are that they require expensive chemicals and the products generated after dye treatment are also polluting in nature $[11,12]$. Biological methods to degrade dyes include enzymes and microorganisms and are found to be effective but the difficulty is to scale up the process [13]. Membrane-filtration processes, electrodialysis, and adsorption involve physical processes which are cheaper compared to biological methods but the maintenance of membranes is expensive [14-16]. Electrochemical process, electrokinetic coagulation, irradiation with light, and photochemical oxidation have been employed for the removal of dye effluents [17]. Major limitations of the above methods are the operating cost, generation of byproducts, and the process of regeneration of the starting compounds which are difficult or tedious [10]. Therefore, degradation of dyes into its smaller fragments of less toxic organic compounds is one of the major challenges faced by scientists, technologists, and researchers across the world. Development of catalysts which can interact with sunlight and degrade the toxic dyes into its low molecular weight colourless and nontoxic fragments which can be discharged into the water bodies without affecting their physicochemical properties is the major objective. Photocatalytic degradation using solar light is the preferred method due to its simplicity and cost effectiveness. Various types of photocatalysts such as perovskites, titanates, zinc oxide, niobates, calcium oxide, and nanoparticle-nickel oxide composite and semiconductors have been widely used [18-27] in degrading different kinds of reactive dyes. The above compounds used are wide band gap semiconductors or insulating in nature and hence are not effective in absorbing visible light or induce electron-hole transitions in the UV region. In search of an alternative, in this paper, we have used, ecofriendly and economically, viable photocatalyst, that is, calcium oxide, for the degradation of indigo carmine dye and the degradation is close to $100 \%$. 


\section{Experimental Section}

2.1. Materials Used. Calcium oxide and indigo carmine dye were procured from commercial source (Spectrum chemicals and SD-Fine Chemicals, India) and were used as received.

2.2. Preparation of Indigo Carmine Dye Solution. Stock solution of indigo carmine dye was prepared by dissolving $50 \mathrm{mg}$ of indigo carmine dye in $1000 \mathrm{~cm}^{3}$ of distilled water.

From the stock solution $\left(1.0721 \times 10^{-4} \mathrm{M}\right), 10 \mathrm{~mL}, 20 \mathrm{~mL}$, $30 \mathrm{~mL}, 40 \mathrm{~mL}$, and $50 \mathrm{~mL}$ solutions were taken and diluted to $100 \mathrm{~mL}$ to prepare $1.0721 \times 10^{-5} \mathrm{M}$ to $1.0721 \times 10^{-4} \mathrm{M}$ ) solutions.

2.2.1. Characterization. Calcium oxide was characterized using Bruker D-8 advanced X-ray powder diffractometer with $\mathrm{Cu} \mathrm{K} \alpha=1.5418 \AA$, scan rate $2^{\circ} \mathrm{min}^{-1}$ (steps: $0.02^{\circ}$ ); scan range of $10-55^{\circ}$. The absorbance measurements of the dye solutions were carried out using Elico CL-63 colorimeter at $\lambda_{\max }=600 \mathrm{~nm}$ (for the dye solutions at $\mathrm{pH} 9-10$ and 12; dye concentration was $1.0721 \times 10^{-4} \mathrm{M}$ and correlates with Beer Lambert's law. The $\mathrm{pH}(\mathrm{pH}=3, \mathrm{pH}=6, \mathrm{pH}=9$, $\mathrm{pH}=12$ ) of the indigo carmine dye solutions of different concentrations-1.0721 $\times 10^{-5} \mathrm{M}, 2.1442 \times 10^{-5}, 3.2195 \times$ $10^{-5} \mathrm{M}, 4.2884 \times 10^{-5} \mathrm{M}, 5.3605 \times 10^{-5} \mathrm{M}$, and $1.0721 \times$ $10^{-4} \mathrm{M}$ was adjusted using either $1 \mathrm{M} \mathrm{HCl}$ or $1 \mathrm{M} \mathrm{NaOH}$ and absorbance data was collected. The indigo carmine dye solutions with different doses of calcium oxide photocatalyst $(0.03 \mathrm{~g}, 0.06 \mathrm{~g}, 0.09 \mathrm{~g}$, and $0.12 \mathrm{~g})$ were exposed to visible light (white light tube), long UV $(\lambda=365 \mathrm{~nm})$, and short UV $(\lambda=254 \mathrm{~nm})$ sources in a closed chamber separately and the changes in the absorbance were measured to estimate the percentage of degradation with time. The percentage of degradation was calculated by comparing the experimental values of absorbance at $\mathrm{pH}=9-10$ and 12 , respectively.

The experiments were performed at room temperature and the degradation studies were measured at $600 \mathrm{~nm}$ using $1.0721 \times 10^{-4} \mathrm{M}$ concentrated indigo carmine dye solution and the absorbance was $0.64-0.65$. The standard deviations were $\pm 3 \%$ in all the measurements between the two consecutive measurements in the same conditions. Experiments were carried out in absence of calcium oxide at different wavelength of light sources. It was found that there is less than $1 \%$ change in the concentration without catalyst. We have reported the optimum conditions in which the experiments were performed. The concentration of indigo carmine dye is $1.0721 \times 10^{-4} \mathrm{M}, \mathrm{pH} 9-10$, calcium oxide dose-0.12 g, and temperature $298 \mathrm{~K}$. The plot of $2+\log A$ as a function of exposure time was plotted to determine the rate constant for the above optimized conditions.

\section{Results and Discussion}

The structure of indigo carmine dye $\left(\mathrm{C}_{14} \mathrm{H}_{8} \mathrm{O}_{4}\right)$ is shown in Scheme 1.

Figure 1 shows the powder X-ray diffraction pattern of calcium hydroxide sample. The reflections match well with the ICSD database. The powder X-ray diffraction pattern of

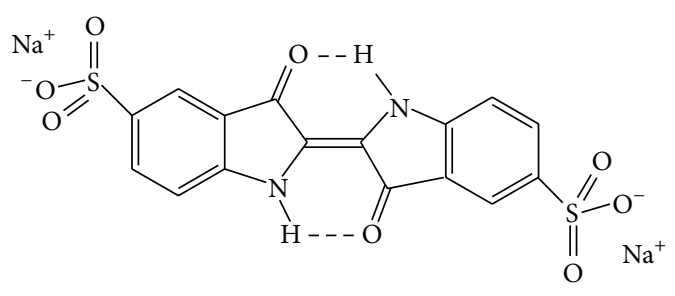

Scheme 1: Structure of sodium salt of indigo carmine dye.

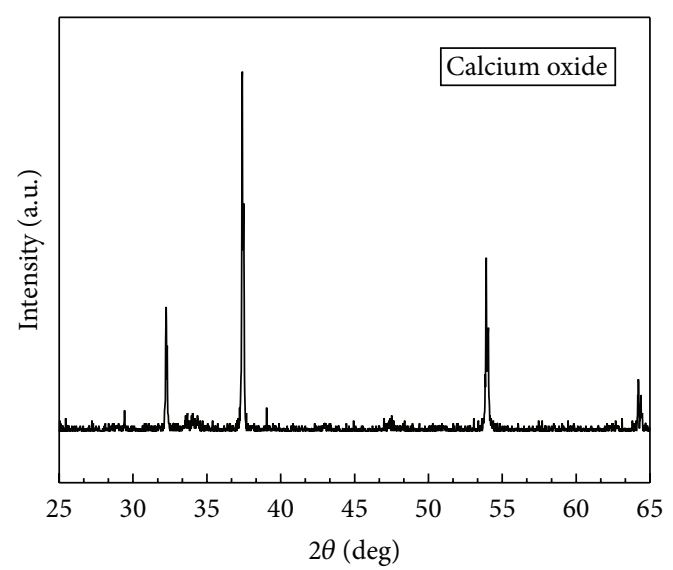

Figure 1: Powder X-ray diffraction pattern of calcium oxide.

TABLE 1: Particle size estimated using Scherer formula for calcium oxide along selective directions.

\begin{tabular}{lcccc}
\hline Photocatalyst & \multicolumn{4}{c}{$(h k l)$ planes } \\
\hline Calcium oxide & $(111)$ & $(002)$ & $(022)$ & $(113)$ \\
Particle size $(\mathrm{nm})$ & 30 & 30 & 36 & 30 \\
\hline
\end{tabular}

calcium oxide was used to estimate the particle size using Scherrer formula:

$$
D=\frac{0.9 \lambda}{\beta \cos \theta}
$$

where $D$ is the average crystallite size in angstroms, $\lambda$ is the wavelength of $\mathrm{X}$-ray source, that is, $\lambda=1.5418 \AA, \theta$ is the diffracted angle, and $\beta$ is the full width at half maximum (FWHM) of different reflections.

The pXRD pattern will provide an average particle size compared to electron microscopic image; hence the particle size of calcium oxide was estimated using Scherrer formula and is in the range of $30-40 \mathrm{~nm}$ (see Table 1). Figure 2 shows the scanning electron micrograph of calcium oxide and the particles are agglomerated and are not clearly evident.

3.1. Effect of Light Source. Photodegradation of indigo carmine dye was carried out using different light sources of different wavelengths, that is, short UV $254 \mathrm{~nm}$, long UV $365 \mathrm{~nm}$, and visible light, using $8 \mathrm{~W}$ lamps which were used as sources (the energy of the radiation intensities is in the range of 0-9.9 joules). The experiments of irradiation of light source on the dye solutions were carried out at $298-300 \mathrm{~K}$. The rate 


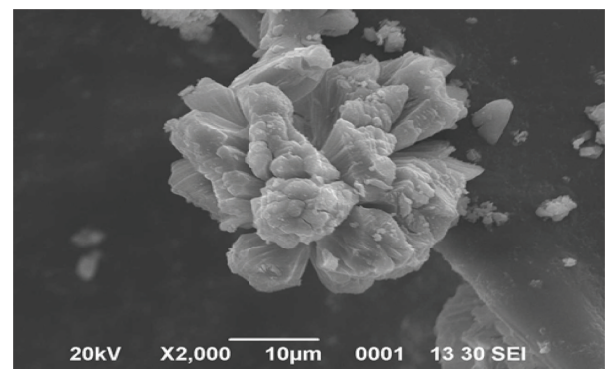

Figure 2: Scanning electron micrograph of calcium oxide.

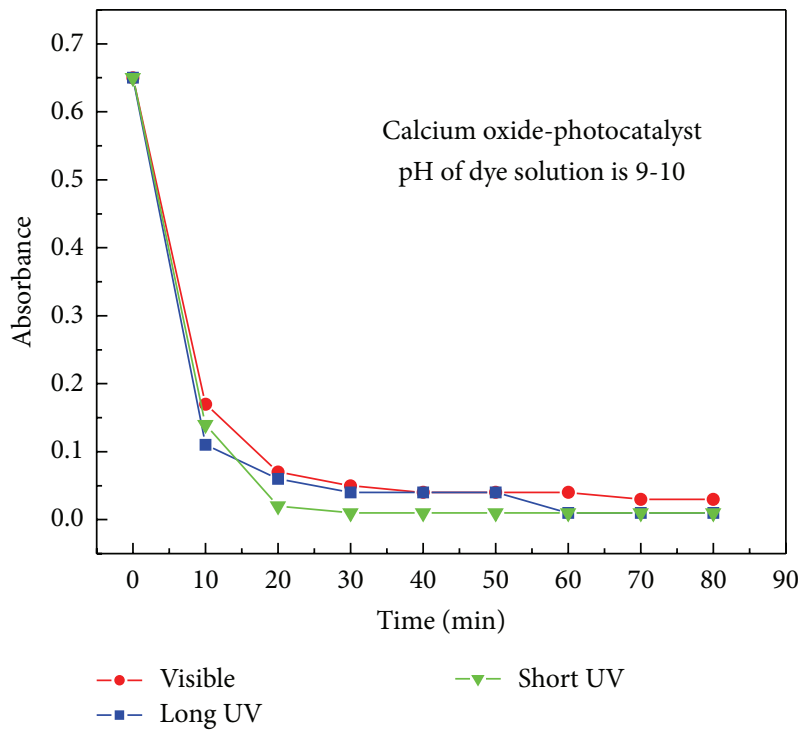

Figure 3: Rate of change of absorbance for indigo carmine onto calcium oxide at $\mathrm{pH}$ 9-10.

of change of concentration was monitored by measuring the absorbance at regular intervals.

3.2. Effect of $p H$. The rate of change of absorbance and the percentage of degradation of indigo carmine using $0.12 \mathrm{~g}$ of calcium oxide catalyst (optimum quantity) were carried out at different light sources (short UV, long UV, and visible light) and the dye solutions were maintained at $\mathrm{pH}$ 9-10 and 12 separately. The rate of photodegradation experiments was also carried out at natural $\mathrm{pH}$ (i.e., $\mathrm{pH}$ attained when calcium oxide is added to the dye solution), that is, $\mathrm{pH}$ 9-10. Attempt to carry out the measurement of degradation of dye at $\mathrm{pH}<7$ was not successful, due to the dissolution of small percentage of calcium oxide at $\mathrm{pH}<7$. Figures 3 and 4 show the rate of absorbance of indigo carmine at different $\mathrm{pH}$ values as a function of time. The rate of degradation of indigo carmine at different light wavelengths and $\mathrm{pH}$ values is shown in Figures 5 and 6 . The degradation of dye solution is found to be more effective when the $\mathrm{pH}>8$. At $\mathrm{pH} 9-10$, dye adsorption onto calcium oxide catalyst, followed by the degradation, was observed. Complete degradation of dye depends on the nature of the photocatalyst and also its interaction with the frequency of light used. From data, it is clearly evident that

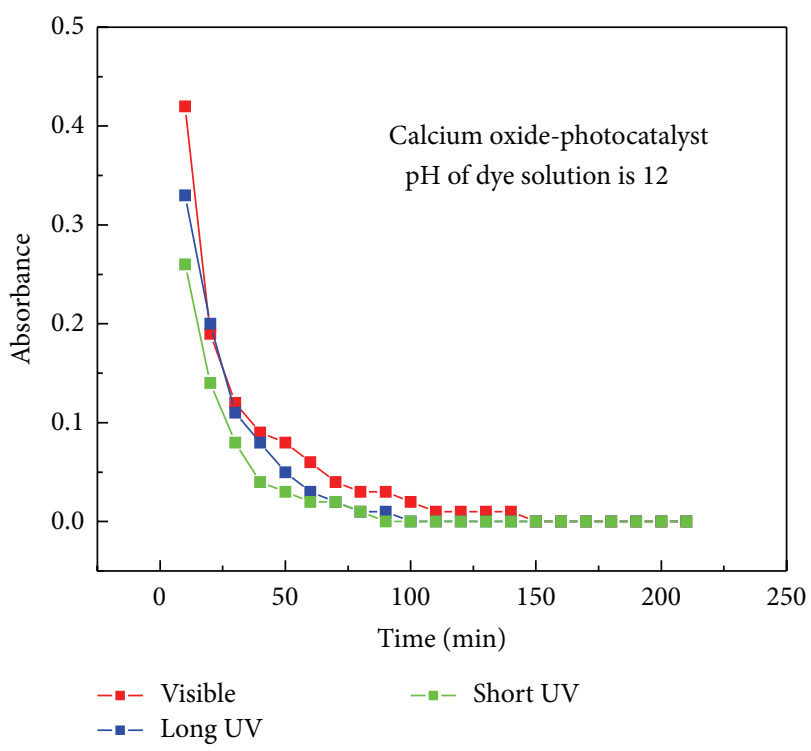

FIGURE 4: Rate of change of absorbance for indigo carmine onto calcium oxide at $\mathrm{pH} 12$.

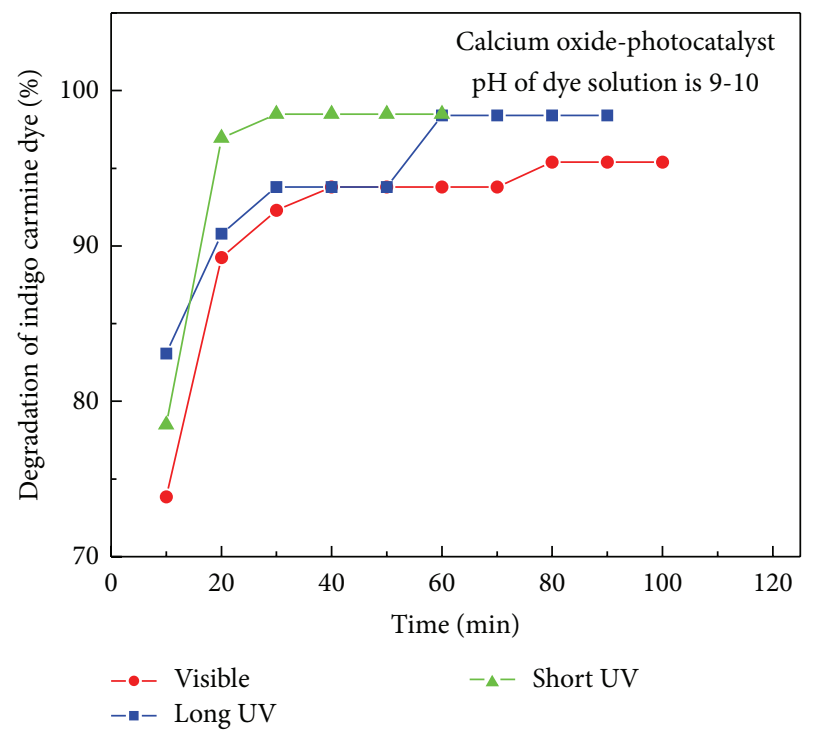

FIGURE 5: Percentage of photodegradation of indigo carmine onto calcium oxide at $\mathrm{pH}$ 9-10.

the rate of degradation is more effective when short UV was used and the dye solution was maintained at $\mathrm{pH}$ 9-10. The duration required for the adsorption followed by degradation of dye is 50 minutes at $\mathrm{pH}$ 9-10 (95.3\% degradation) for short UV compared to long UV (60 min; 95.3\% degradation) and visible light ( 80 min; $95.3 \%$ degradation). At $\mathrm{pH} 12,100 \%$ degradation was observed but the rate at which the process occurs is slower in nature (Table 2). Figures 7 and 8 show the graphs of rate of change of concentration of indigo carmine dye with time at $\mathrm{pH} 9-10$ and 12 , respectively. This clearly indicates that photodegradation is more effective at lower wavelength radiation (short UV), due to the higher energy associated with it. 
TABLE 2: The effect of irradiation of different light sources on the percentage of degradation of indigo carmine dye solution using calcium oxide.

\begin{tabular}{lccccc}
\hline Photocatalyst & Light source & $\begin{array}{c}\text { Contact time (min) } \\
(\mathrm{pH} \text { of dye solution is 9-10) }\end{array}$ & $\begin{array}{c}\text { Percentage of degradation } \\
(\text { dye at } \mathrm{pH} \mathrm{9-10)}\end{array}$ & $\begin{array}{c}\text { Contact time (min) } \\
(\mathrm{pH} \text { of dye solution is 12) }\end{array}$ & $\begin{array}{c}\text { Percentage of } \\
\text { degradation of dye } \\
(\mathrm{pH} 9-10)\end{array}$ \\
\hline \multirow{2}{*}{$\begin{array}{l}\text { 0.12 g calcium } \\
\text { oxide }\end{array}$} & Visible & 70 & 95.4 & 150 & 100 \\
& Long UV & 60 & 98.4 & 100 & 100 \\
& Short UV & 30 & 98.48 & 90 & 100 \\
\hline
\end{tabular}

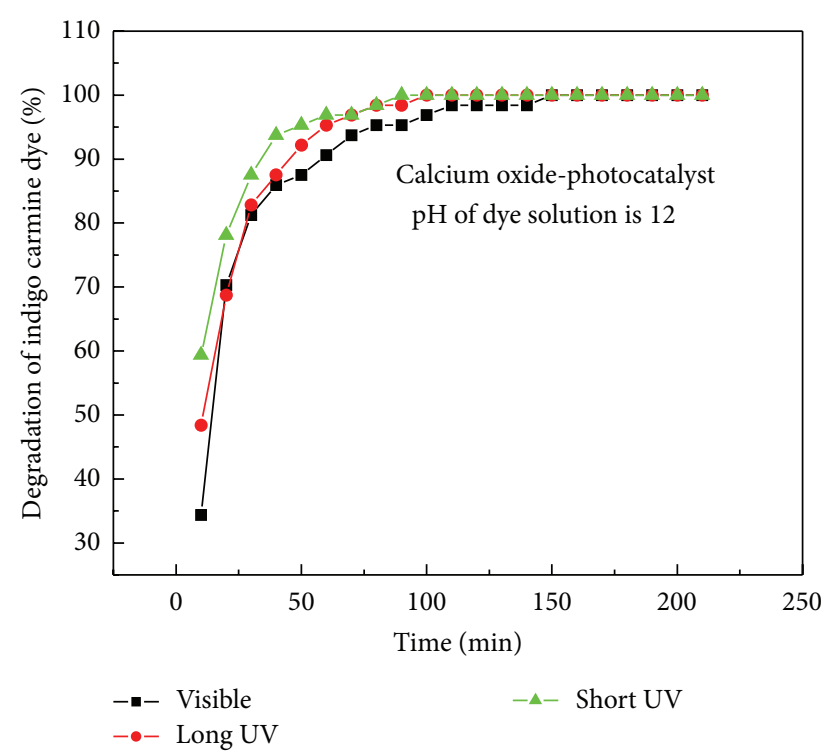

Figure 6: Percentage of photodegradation of indigo carmine onto calcium oxide at $\mathrm{pH} 12$.

It was found that when short UV was used, dye can be effectively degraded at short duration compared to visible and long UV region. The mechanism for the degradation of dye using brilliant red azo dye using calcium oxide and calcium oxide magnesium oxide composite nanoparticles has been reported [19]. The reported band gap of calcium oxide nanoparticle is in the range of 5 to $8 \mathrm{eV}$, indicating that it is an insulator. Promotion of electron from valence band to conduction band demands higher energy radiation and most of the time we may not observe transition. The plot of " $q$ " versus " $t$ " indicates that Langmuir type of adsorption and the equilibrium to reach depends on the light source used for the degradation (see Figure 9).

3.3. Mechanism of Dye Degradation. The mechanism of dye degradation is as follows:

$$
\begin{gathered}
{ }^{1} \mathrm{Dye}_{\mathrm{o}}^{-} \longrightarrow{ }^{1} \mathrm{Dye}_{1}{ }^{-*} \\
{ }^{1} \mathrm{Dye}_{\mathrm{o}}{ }^{-*} \longrightarrow{ }^{3} \mathrm{Dye}_{1}{ }^{-*} \\
\mathrm{CaO}+\mathrm{h} v \longrightarrow \mathrm{e}^{-}(\mathrm{CB})+\mathrm{h}^{+}(\mathrm{VB}) \\
\mathrm{e}^{-}(\mathrm{CB})+\mathrm{O}_{2} \longrightarrow \mathrm{O}_{2}{ }^{--}
\end{gathered}
$$

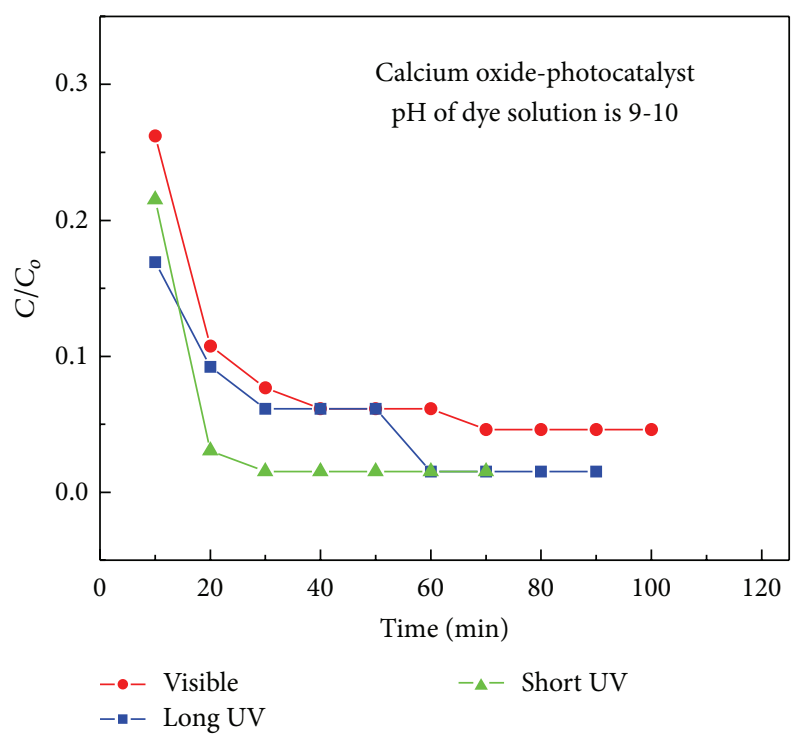

FIgURE 7: Rate of change of concentration of indigo carmine as a function of time at $\mathrm{pH}$ 9-10.

$$
\begin{gathered}
\mathrm{H}_{2} \mathrm{O}+\mathrm{O}_{2}^{\cdot-} \longrightarrow \mathrm{OOH}^{\bullet}+\mathrm{OH}^{-} \\
\mathrm{O}_{2}^{\cdot-}+\text { dye } \longrightarrow \text { dye }-\mathrm{OO}^{\bullet} \\
\mathrm{OOH}^{\bullet}+\mathrm{H}_{2} \mathrm{O}+\mathrm{e}^{-}(\mathrm{CB}) \longrightarrow \mathrm{H}_{2} \mathrm{O}_{2}+\mathrm{OH}^{\bullet-} \\
\mathrm{H}_{2} \mathrm{O}_{2}+\mathrm{e}^{-}(\mathrm{CB}) \longrightarrow \mathrm{OH}^{-}+\mathrm{OH}^{-} \\
\mathrm{H}_{2} \mathrm{O}_{2}+\mathrm{O}_{2}^{\cdot-} \longrightarrow \mathrm{OH}^{\bullet}+\mathrm{OH}^{-}+\mathrm{O}_{2} \\
\frac{\mathrm{OH}^{\bullet}}{\mathrm{O}_{2}^{\cdot-}} \longrightarrow \mathrm{CaO}^{\bullet}+\text { dye degradation }^{\longrightarrow} \\
\mathrm{h}^{+}(\mathrm{VB})+\mathrm{OH}^{-} \longrightarrow \text { OH } \\
\mathrm{OH}^{\bullet}+\text { dye } \longrightarrow \text { degraded products }
\end{gathered}
$$

Ground state dye molecules absorb radiation and get promoted to singlet excited state from which it will undergo intersystem crossover to triplet state. Valence band electrons in calcium oxide will absorb radiation and get promoted to conduction band thus generating hole. The valence electron will react with the dissolved oxygen molecule in the solution to generate $\mathrm{O}_{2}{ }^{--}$radical. $\mathrm{O}_{2}{ }^{--}$radicals react with dye molecule to generate dye superoxide ion thus degrading into 


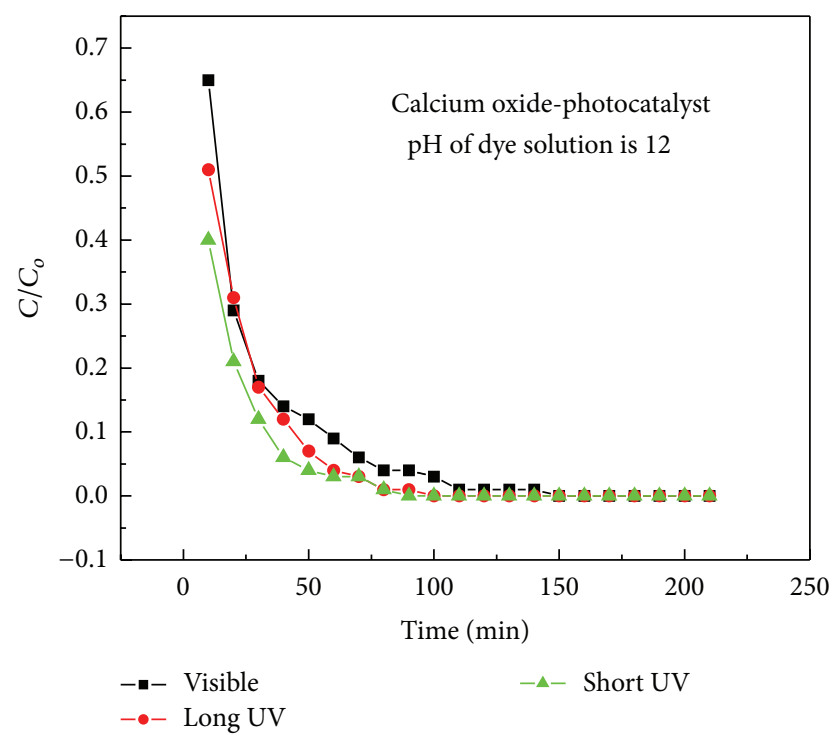

FIGURE 8: Rate of change of concentration of indigo carmine as a function of time at $\mathrm{pH} 12$.

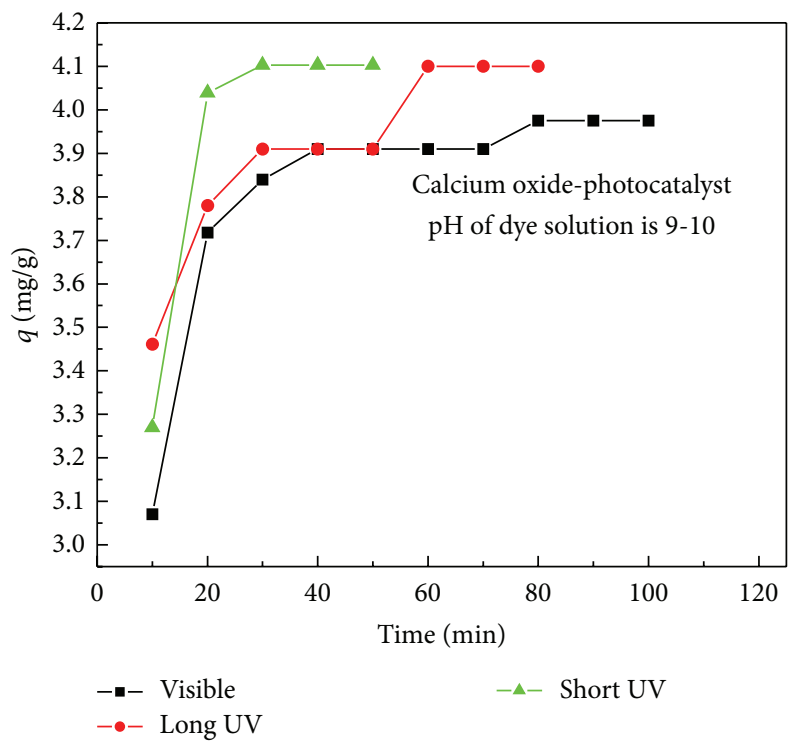

FIGURE 9: Kinetics of adsorption of indigo carmine on calcium oxide.

carbon dioxide and water molecules. On the other hand, holes present in the valence band will react with hydroxyl ions to generate hydroxyl-free radical which attacks dye to generate degraded products. Calcium oxide nanoparticles will possess large band gap due to which they may be poor semiconductors or insulators and hence are not effective in absorbing visible light or induce electron-hole transitions in the UV region.

A decrease in absorbance value of indigo carmine dye solution was observed with time and a plot of $2+\log A$ was plotted against time to measure the rate constant. The effect of calcium oxide photocatalyst in indigo carmine at $\mathrm{pH}$ 9-10 and 12 on irradiation of different wavelength sources on the rate constants is given in Tables 3 and 4, respectively.
TABLE 3: The effect of irradiation of different light sources on exposure to indigo carmine dye solution using calcium oxide at $\mathrm{pH}$ 9-10 on rate constant values.

\begin{tabular}{lcc}
\hline Photocatalyst & Light source & Rate constant $\left(\mathrm{min}^{-1}\right)$ \\
\hline \multirow{3}{*}{$0.12 \mathrm{~g}$ calcium oxide } & Visible & 0.01486 \\
& Long UV & - \\
& Short UV & 0.0376 \\
\hline
\end{tabular}

TABLE 4: The effect of irradiation of different light sources on exposure to indigo carmine dye solution using calcium oxide at $\mathrm{pH}$ 12 on rate constant values.

\begin{tabular}{lcc}
\hline Photocatalyst & Light source & Rate constant $\left(\mathrm{min}^{-1}\right)$ \\
\hline \multirow{3}{*}{$0.12 \mathrm{~g}$ calcium oxide } & Visible & 0.04938 \\
& Long UV & 0.04604 \\
& Short UV & 0.03233 \\
\hline
\end{tabular}

\section{Conclusions}

The optimized conditions for the photochemical degradation of indigo carmine dye solution using of calcium oxide are as follows:

(i) $0.12 \mathrm{~g}$ of calcium oxide, (ii) effective $\mathrm{pH}$ for dye degradation which is $9-10$, (iii) indigo carmine dye concentration used-5.0 mg/100 mL, (iv) temperature: $298-300 \mathrm{~K}$, and (v) contact time which is less when short UV light source was used.

The results demonstrate that calcium oxide can be used as an effective low cost photocatalyst for the successful degradation of water soluble indigo carmine dye solution. The photocatalytic degradation process does not require heating, chemical treatment, modifiers, and so forth.

\section{Conflict of Interests}

The authors declare that there is no conflict of interests regarding the publication of this paper.

\section{Acknowledgments}

The authors would like to gratefully thank Tumkur University for their encouragement, support, and facilities. Ramesh Thimmasandra Narayan expresses his deepest gratitude to Professor P. Vishnu Kamath for extending unconditional support throughout his academic career and for permitting the use of powder X-ray diffraction facilities and Dr. Ujjal Gautham of JNCSR, Bangalore, for his kind help in collection of SEM image.

\section{References}

[1] R. M. Christie, Environmental Aspects of Textile Dyeing, Wood Head, Boca Raton, Fla, USA, 2007.

[2] B. R. Babu, A. K. Parande, S. Raghu, and T. Prem Kumar, "Cotton textile processing: waste generation and effluent treatment," Journal of Cotton Science, vol. 11, no. 3, pp. 141-153, 2007. 
[3] J. S. Bae and H. S. Freeman, "Aquatic toxicity evaluation of new direct dyes to the Daphnia magna," Dyes and Pigments, vol. 3, pp. 81-85, 2007.

[4] R. Helmer and I. Hespanhol, Water Pollution Control-A Guide to the Use of Water Quality Management Principles, E \& FN Spon, London, UK, 1997.

[5] F. I. Hai, K. Yamamoto, and K. Fukushi, "Hybrid treatment systems for dye wastewater," Critical Reviews in Environmental Science and Technology, vol. 37, no. 4, pp. 315-377, 2007.

[6] M. N. Chong, B. Jin, C. W. K. Chow, and C. Saint, "Recent developments in photocatalytic water treatment technology: a review," Water Research, vol. 44, no. 10, pp. 2997-3027, 2010.

[7] J. A. Byrne, P. A. Fernandez-Ibañez, P. S. M. Dunlop, D. M. A. Alrousan, and J. W. J. Hamilton, "Photocatalytic enhancement for solar disinfection of water: a review," International Journal of Photoenergy, vol. 2011, Article ID 798051, 12 pages, 2011.

[8] M. R. Hoffmann, S. T. Martin, W. Choi, and D. W. Bahnemann, "Environmental applications of semiconductor photocatalysis," Chemical Reviews, vol. 95, no. 1, pp. 69-96, 1995.

[9] K. Pirkanniemi and M. Sillanpää, "Heterogeneous water phase catalysis as an environmental application: a review," Chemosphere, vol. 48, no. 10, pp. 1047-1060, 2002.

[10] Y. M. Slokar and A. Majcen le Marechal, "Methods of decoloration of textile wastewaters," Dyes and Pigments, vol. 37, no. 4, pp. 335-356, 1998.

[11] A. Al-Kdasi, A. Dris, K. Saed, and K. C. T. Guan, "Photoluminescence and photocatalysis of the flower-like nano- $\mathrm{ZnO}$ photocatalysts prepared by a facile hydrothermal method with or without ultrasonic assistance," Global Nest: The International Journal, vol. 6, pp. 222-230, 2004.

[12] I. D. Mall, S. N. Upadhyay, and Y. C. Sharma, "A review on economical treatment of wastewaters and effluents by adsorption," International Journal of Environmental Studies, vol. 51, no. 2, pp. 77-124, 1996.

[13] A. Khalid, M. Arshad, and D. E. Crowley, "Accelerated decolorization of structurally different azo dyes by newly isolated bacterial strains," Applied Microbiology and Biotechnology, vol. 78, no. 2, pp. 361-369, 2008.

[14] G. Crini, "Non-conventional low-cost adsorbents for dye removal: a review," Bioresource Technology, vol. 97, no. 9, pp. 1061-1085, 2006.

[15] A. Dabrowski, "Adsorption-from theory to practice," Advances in Colloid and Interface Science, vol. 93, no. 1-3, pp. 135-224, 2001.

[16] R. Wanchanthuek and W. Nunrung, "The adsorption study of Methylene Blue onto $\mathrm{MgO}$ from various preparation methods," Journal of Environmental Science and Technology, vol. 4, no. 5, pp. 534-542, 2011.

[17] M. C. Gutiérrez and M. Crespi, "A review of electrochemical treatments for colour elimination," Coloration Technology, vol. 115, no. 11, pp. 342-345, 1999.

[18] Y. Lai, M. Meng, Y. Yu, X. Wang, and T. Ding, "Photoluminescence and photocatalysis of the flower-like nano- $\mathrm{ZnO}$ photocatalysts prepared by a facile hydrothermal method with or without ultrasonic assistance," Applied Catalysis B: Environmental, vol. 105, no. 3-4, pp. 335-345, 2011.

[19] E. A. Konstantinova, A. I. Kokorin, S. Sakthivel, H. Kisch, and K. Lips, "Carbon-doped titanium dioxide: visible light photocatalysis and EPR investigation," Chimia, vol. 61, no. 12, pp. 810-814, 2007.
[20] W. Cun, Z. Jincai, W. Xinming et al., "Preparation, characterization and photocatalytic activity of nano-sized $\mathrm{ZnO} / \mathrm{SnO}_{2}$ coupled photocatalysts," Applied Catalysis B: Environmental, vol. 39, no. 3, pp. 269-279, 2002.

[21] L. Song and S. Zhang, "A simple mechanical mixing method for preparation of visible-light-sensitive $\mathrm{NiO}-\mathrm{CaO}$ composite photocatalysts with high photocatalytic activity," Journal of Hazardous Materials, vol. 174, no. 1-3, pp. 563-566, 2010.

[22] L. Song, S. Zhang, B. Chen, and D. Sun, "Highly active NiO$\mathrm{CaO}$ photocatalyst for degrading organic contaminants under visible-light irradiation," Catalysis Communications, vol. 10, no. 5, pp. 421-423, 2009.

[23] J. Luan, W. Zhao, J. Feng et al., "Structural, photophysical and photocatalytic properties of novel $\mathrm{Bi}_{2} \mathrm{AlVO}_{7}$," Journal of Hazardous Materials, vol. 164, no. 2-3, pp. 781-789, 2009.

[24] J. Luan, M. Li, K. Ma, Y. Li, and Z. Zou, "Photocatalytic activity of novel $\mathrm{Y}_{2} \mathrm{InSbO}_{7}$ and $\mathrm{Y}_{2} \mathrm{GdSbO}_{7}$ nanocatalysts for degradation of environmental pollutant rhodamine $\mathrm{B}$ under visible light irradiation," Chemical Engineering Journal, vol. 167, no. 1, pp. 162-171, 2011.

[25] J. Luan, Z. Zheng, H. Cai, X. Wu, G. Luan, and Z. Zou, "Structural characterization and photocatalytic properties of novel $\mathrm{Bi}_{2} \mathrm{YVO}_{8}$," Materials Research Bulletin, vol. 43, no. 12, pp. 3332-3344, 2008.

[26] J. Luan, H. Cai, X. Hao et al., "Structural characterization and photocatalytic properties of novel $\mathrm{Bi}_{2} \mathrm{FeVO}_{7}$," Research on Chemical Intermediates, vol. 33, no. 6, pp. 487-500, 2007.

[27] T. Kornprobst and J. Plank, "Photodegradation of rhodamine $\mathrm{B}$ in presence of $\mathrm{CaO}$ and $\mathrm{NiO}-\mathrm{CaO}$ catalysts," International Journal of Photoenergy, vol. 2012, Article ID 398230, 6 pages, 2012. 

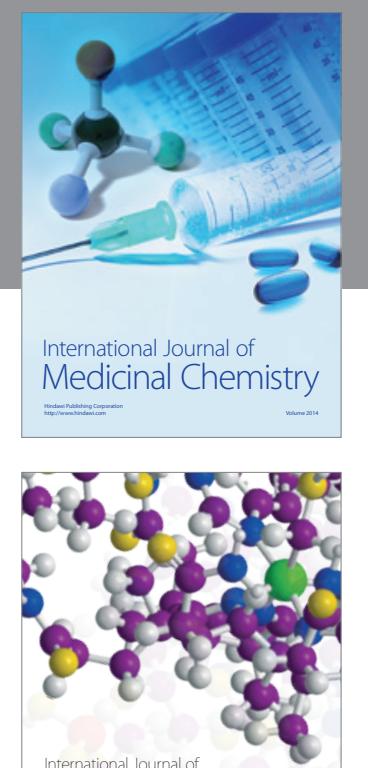

\section{Carbohydrate} Chemistry

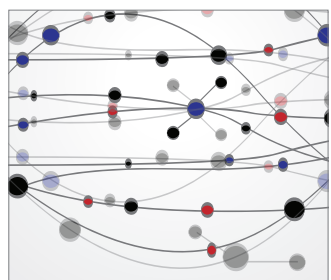

The Scientific World Journal
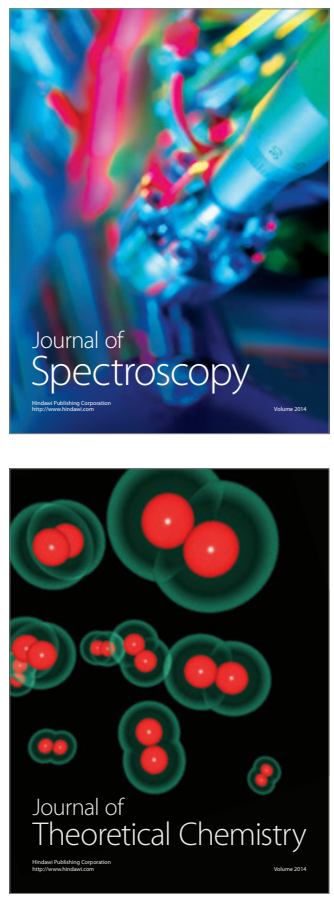
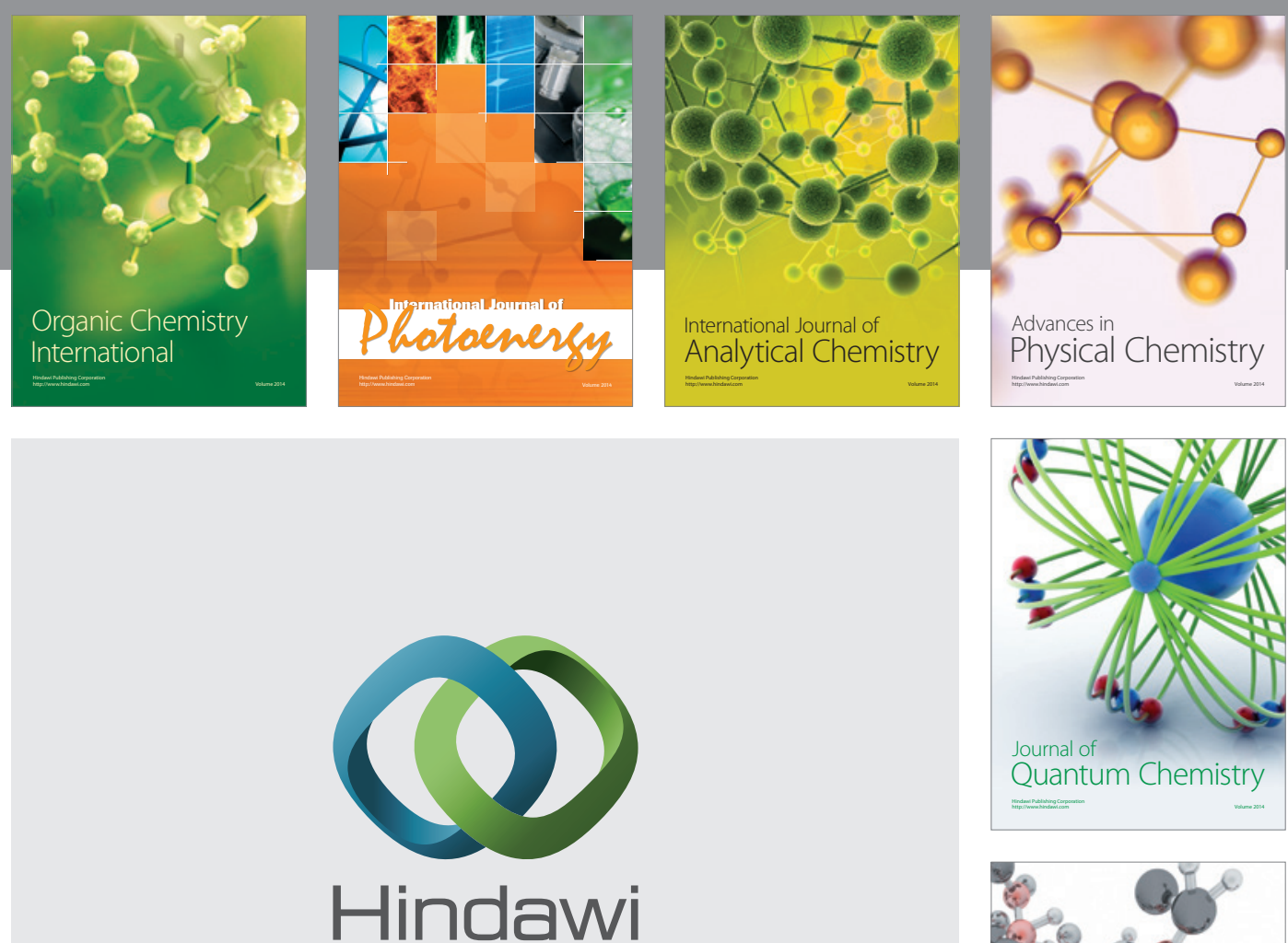

Submit your manuscripts at

http://www.hindawi.com

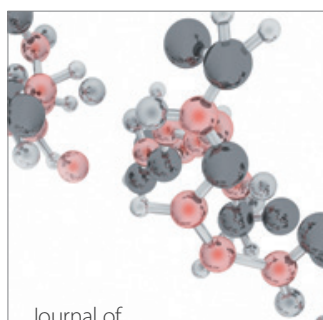

Analytical Methods

in Chemistry

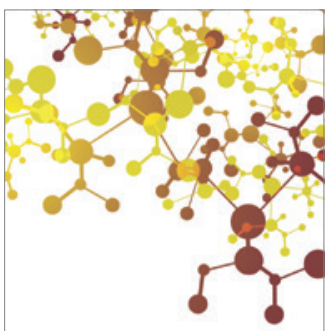

Journal of

Applied Chemistry

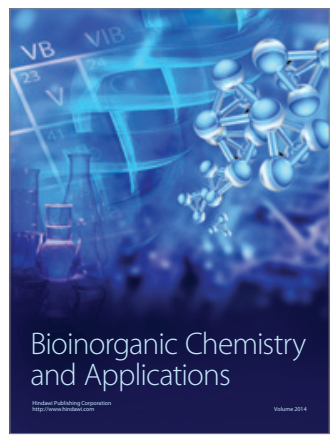

Inorganic Chemistry
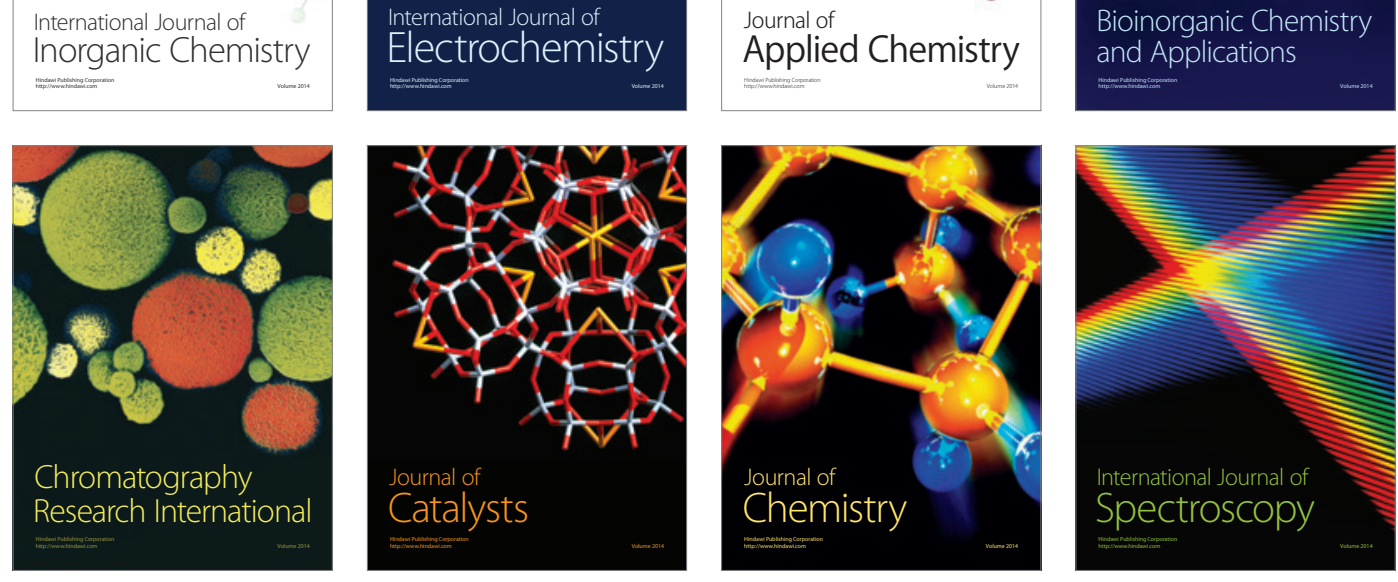